\title{
WestVirginiaUniversity.
}

Department of Economics

Working Paper Series

\section{Was Adam Smith Right About Religious Competition?}

Peter J. Boettke

Joshua C. Hall

Kathleen M. Sheehan

Working Paper No. 15-47

This paper can be found at the College of Business and Economics Working Paper Series homepage: 


\title{
Was Adam Smith Right About Religious Competition?
}

\author{
Peter J. Boettke \\ University Professor of Economics \\ Department of Economics \\ George Mason University \\ MSN 3G4 \\ Fairfax, VA 22030 \\ pboettke@gmu.edu \\ Joshua C. Hall \\ Associate Professor of Economics \\ College of Business and Economics \\ West Virginia University \\ Morgantown, WV 26506 \\ joshua.c.hall@gmail.com \\ Kathleen M. Sheehan \\ Assistant Professor of Economics \\ Heider College of Business \\ Creighton University \\ Omaha, NE 68178 \\ kathleensheehan@creighton.edu
}

\begin{abstract}
Adam Smith famously argued that increased competition in religion would result in more religious tolerance and that the benefits of competition in the marketplace would also be seen in religious instruction when many religious sects are tolerated. We use a cross-section of a maximum of 167 countries to explore whether increased religious competition results in less governmental regulation of religion and less governmental favoritism of religion. Our measure of religious regulation and favoritism comes from the Association of Religion Data Archives. Our empirical analysis also explores the influence of economic and political factors, including the size of the economy, openness of trade, legal origins, education, the amount of checks and balances on the government and the role of democracy.
\end{abstract}

JEL Codes: Z12

Keywords: religious freedom; regulation; democracy 


\section{Introduction}

Adam Smith (1776, Book V, Chapter 1, 309ff) famously argued that competition in religion would instill more religiosity in the population as teachers of religious doctrine would be incentivized to be more effective communicators. ${ }^{1}$ "The teachers of the doctrine which contains this instruction, in the same manner as other teachers, may either depend altogether for their subsistence upon the voluntary contribution of their hearers; or they may derive it from some other fund to which the law of their country may entitle them; such as a landed estate, a tythe or land tax, an established salary or stipend. Their exertion, their zeal and industry, are likely to be much greater in the former situation than in the latter." (emphasis added) Rather than the "indolence" often witnessed in instructors of established religions, the upstart churchmen are "kept more alive by the powerful motive of self-interest” (Smith 1776, p. 310-311).

Smith goes on to suggest that religiosity and zeal can be problematic - in fact dangerous and troublesome - when only one religion is tolerated in a society, or when a country is divided between only two or three sects. But where religious freedom reigns, Smith contends, religious "zeal must be altogether innocent." In a society where "two or three hundred” religious sects are tolerated, “no one could be considerable enough to disturb the public tranquility.” (Smith 1776, p. 314) Thus, Smith’s argument for religious toleration mimics his overall argument for economic liberalism. Smith was an ardent critic of monopoly in commerce as well as in religious instruction. He believed that

\footnotetext{
${ }^{1}$ Anderson (1988) provides the seminal overview of the economics of religion contained in The Wealth of Nations.
} 
under conditions of open competition, the self-interest of each of the parties would direct them to pursue actions which resulted in productive specialization and peaceful cooperation.

Anthony Gill (2013) has argued that religious liberty is positively correlated with economic development through a variety of channels - namely an idea channel and an acquisition of human capital channel. Conversely, Anderson and Tollison (1992) argue that a monopoly in morals can be conducive to economic growth since religious competition can lead to the underprovision of moral order. ${ }^{2}$ We are not exploring these hypotheses. Instead, we are limiting our exploration to the claim that religious competition (fractionalization) results in less government regulation of religion as well as government favoritism of religion. This is true controlling for legal origins, democracy, and checks and balances. But Smith’s observation that improvements in arts, manufacturing and commerce destroys not only the power of the barons, but also throughout the greater part of Europe the monopolistic power of the clergy (Smith 1776, p. 325). Competition, in this sense, erodes religious power just as it does economic power and leads to improvement in well-being among the people.

\section{Data and Empirical Approach}

\footnotetext{
${ }^{2}$ Other papers looking at religious competition and outcomes include Lipford et al. (1993) and Lipford and Yandle (1997). For example, Lipford and Yandle (1997) use the litigiousness of a state as a proxy for 'formally produced order' and find that greater religious concentration in a state leads to more 'formally produced order.'
} 
Our source of data on religious freedom comes from the Association of Religion Data Archives (2015). The Office of International Religious Freedom within the U.S. State Department is tasked with promoting religious freedom. One of the ways it does so is by producing the Annual Report on International Religious Freedom (Bureau of Democracy, Human Rights and Labor, 2013). Produced annually since 2001, this annual report to Congress discusses in a narrative format government policies violating religious freedom for nearly 200 countries.

In part due to a grant from the John Templeton Foundation, researchers for the Association of Religion Data Archives systematically coded the material found in the 2003, 2005, and 2008 reports to create indices of religious freedom across a large number of countries. Using a coding instrument, researchers went through the reports to try to quantify different measures of religious freedom. A full description of this effort and process can be found in Grim and Finke (2006). Their efforts produce two quantitative measures of government regulation and favoritism of religion across 199 countries and territories, averaged over the sample period. ${ }^{3}$

Two variables produced in the indices are the Government Regulation of Religion Index (GRRI) and the Government Favoritism of Religion Index (GFRI). From a classical liberal perspective, the GRRI is the most straightforward measure of the two measures to interpret. In describing the measure, Grim and Finke (2006, p. 7) say that government regulation is "the restrictions placed on the practice, profession, or selection of religion by the official laws, policies, or administrative actions of the state.” In

\footnotetext{
${ }^{3}$ Association of Religion Data Archives (2015) recommends that social scientists using the data for empirical modelling use their measure aggregated over the three years since it has less yearto-year randomness.
} 
addition to constitutional provisions protecting religious freedom, this measure also gets at administrative or regulatory burdens that affect all or select religious groups within a country. For example, one of the coding questions included in the GRRI is "Does the Report mention that proselytizing, public preaching, or conversion is limited or restricted?”4 This measure varies from 0 to 10 , with higher numbers representing greater regulation of religion and lower numbers representing more religious freedom. To put this variable in perspective, Sweden scored 0.27 over the 2004-2008 period while Pakistan scored 8.79 during that same period.

The GFRI captures the state actions that privilege or support one religion or a group of religions. State actions that favor one particular religion include things like having a state religion, direct financial subsidies, or tax breaks such as tax-exempt status. The GFRI provides higher scores to countries that are more selective in their favoritism. For example, countries that fund things related to religion but all religions have access to funding receive lower scores than countries where government only funds a selected group of religions. ${ }^{5}$ While less straightforward in terms of testing Adam Smith’s conjecture, we include the GFRI in our empirical analysis because we feel that the same argument regarding religious competition should be related to government favoritism of religion in addition to government regulation of religion. ${ }^{6}$ Like the GRRI, the GFRI

\footnotetext{
${ }^{4}$ The six questions included in the GRRI can be found on p. 13 of Grim and Finke (2006).

${ }^{5}$ For more information on the five questions and coding used to calculate the GFRI, see Grim and Finke (2006, p. 16). The codebook and questions for both the GRRI and GFRI can also be easily obtained online from Association of Religion Data Archives (2015).

${ }^{6}$ Grim and Finke (2006, p. 17) argue that while these two measures are both similar in origin (state action towards religion), empirically they are two separate things according to factor analysis and should not be combined into a common index.
} 
ranges from 0 to 10, with higher numbers representing greater favoritism of religion. Sweden, for example receives a 2.93 on the GFRI, while Pakistan receives an $8.81{ }^{7}$

Our measure of religious competition comes from Alesina et al. (2003). Using data from Encyclopedia Britannica on 294 religions across 215 countries and territories, they calculate the degree of religious fractionalization within a country. Their measure of fractionalization is calculated by the following formula:

$$
\text { RELIGIOUS FRACTIONALIZATION } N_{j}=1-\sum_{i=1}^{N} s_{i j}^{2}
$$

where $s_{i j}$ is the share of each religious group in country $j$. A country where the entire population practiced the same religion would receive a score of 0 and higher numbers representing more religious fractionalization. From our perspective, and related to the view of Adam Smith, fractionalization is the same as competition. A country with very few religions or a dominant religion is likely to keep barriers to entry high, while countries that are extremely fractionalized by religion will be unlikely to have government extensively regulate religion or favor specific religions.

We include additional explanatory variables that might be associated with religious freedom and the intensity of religious preferences. We control for GDP per capita (in log form), trade openness, the education in a country, and legal origins (LaPorta et al. 2003). In addition, we also show how robust our results are to the inclusion of the political institutional measures constitutional checks and balances (Keefer and Stasavage, 2003) and Polity IV democracy scores (Marshall et al. 2013). Table 1 provides a description of each variable, its source, as well as each variables mean

\footnotetext{
${ }^{7}$ It is important to note that since this index is derived from U.S. State Department reports of other countries, the United States is not in either index.
} 
and standard deviation. For GRRI and GFRI, we use the measure aggregated over all years of the index, as suggested by the Association of Religion Data archives. For data that is available yearly, we average the data between 1998 and 2008 to cover the time period examined by our religion measures and to help control for any year to year randomness.

\section{Empirical Results}

Table 2 reports results for our baseline regression in which we examine how the religious fractionalization in a country affects government regulation of religion and government favoritism of religion while controlling for the size of the economy, how open the country is to trade, adult literacy in the country.

Columns (1) and (2) shows that the amount of religious competition in a country, as measured by the religious fractionalization, has a statistically significant negative impact on regulation and favoritism. Countries that have additional religious fractionalization have less government interference in terms of regulations of religion and policies that favor certain religions. A standard deviation increase in the amount of fractionalization within the country is associated with a 22.8 percent decrease in the amount of government regulation of religion in the country. Similarly, column (2) shows that a standard deviation increase in the amount of fractionalization is associated with a 37.2 percent decrease in the amount of government favoritism of religion.

Columns (3) and (4) change our baseline regression to include secondary school enrollment rates instead of adult literacy. Using secondary enrollment as our measure of the education within a country allows us to include an additional 30 countries in our 
study. Religious fractionalization continues to have a statistically significant negative impact of government interference in religion.

It is possible that the legal origins of a country also impact the regulations and policies toward religion. In columns (5) and (6) we control for the countries legal origins. Fractionalization again seems to reduce regulation and favoritism in religion. A standard deviation increase in fractionalization is associated with a 34.1 percent decrease in government regulation of religion and a 45.1 percent decrease in government favoritism of religion.

These results suggest that Adam Smith’s ideas on religious competition are correct. Countries that have more competition in religion appear to regulate religion less and leave more room for economic actors to pursue actions for productive specialization and cooperation. This is particularly heartening given that previous studies have shown that religious liberty is positively correlated with economic development.

\section{Robustness checks}

The kind of laws and regulations implemented in countries are also a result of the country's political institution. In Table 3 we examine how including political institutions will affect our results. We first control for the amount of checks and balances within the government using the Database of Political Institutions (Keefer and Stasavage 2003) measure. Checks and balances examine the number of 'veto players' that exist in a country's political system. A higher score shows greater constraint on government and that a higher level of consensus is necessary for policies to change. More checks and balances then will likely mean less religious regulation and favoritism. 
Columns (1)-(4) include this measure in our regressions. Our results show that checks and balances do negatively impact government interference. In addition, including this measure of political institutions has not significantly changed the impact of religious fractionalization in countries. Additional fractionalization still leads to less government regulation and favoritism.

The strength of democracy within a country will also likely affect the type of religious laws implemented. A country that is democratic will be constrained by its citizens in adapting laws to limit religious liberty. We use Polity IVs measure of democracy.

Columns (5)-(8) examine how religious fractionalization and democracy affect government inference in religion. Countries that are more democratic appear to experience fewer religious regulations and fewer policies that promote favoritism. The level of religious fractionalization in a country still negatively impacts government interference, though the magnitude of this result has decline slightly. A standard deviation increase in fractionalization is associated with a 27.4 percent decline in religious regulations and a 39.6\% decline in religious favoritism as seen in columns (7) and (8).

\section{$5 \quad$ Concluding Remarks}

Adam Smith hypothesized that competition in religion would lead to a more tolerant government. Countries that have many religions that are allowed to compete will also experience more religious freedom. Where these conditions are met, the self-interest of each of the parties will pursue actions that result in productive specialization and 
peaceful cooperation. This is idea is consistent with previous findings that show that countries with more religious liberty experience more economic development.

We have shown that the amount of religious competition as measured by the amount of religious fractionalization in a country affects governmental laws and regulations as they relate to religion. Countries that are more fractionalized have fewer regulations of religion and their laws and policies also show less favoritism. Our results should not be taken, however, to mean that religious competition leads to greater religiosity as argued by Iannaccone (1991). Or that there might not also be a relationship between government regulation and the competitiveness of the religious marketplace as economic theory would suggest. Further data and research is needed to better test these relationships. 


\section{References}

Alesina, Alberto, Arnaud Devleeschauwer, William Easterly, Sergio Kurlat, and Romain Wacziarg. 2003. “Fractionalization.” Journal of Economic Growth 8 (June): 155-194.

Anderson, Gary M. 1988. "Mr. Smith and the Preachers: The Economics of Religion in the Wealth of Nations.” Journal of Political Economy 96, no. 5: 1066-1088.

Anderson, Gary M., and Robert D. Tollison. 1992. "Morality and Monopoly: The Constitutional Political Economy of Religious Rules.” Cato Journal 12, no. 2: 373-392.

Association of Religion Data Archives. 2015. "International Religious Freedom Data, Aggregate File (2003-2008).” Online at: http://www.thearda.com/Archive/Files/Descriptions/IRFAGG2.asp

Bureau of Democracy, Human Rights and Labor. 2013. International Religious Freedom Report for 2013. Washington, DC: U.S. Department of State.

Grim, Brian J. and Roger Finke. 2006. "International Religion Indexes: Government Regulation, Government Favoritism, and Social Regulation of Religion." Interdisciplinary Journal of Research on Religion 2 (Article 1): 1-40.

Iannaccone, Laurence R. 1991. "The Consequences of Religious Market Structure Adam Smith and the Economics of Religion.” Rationality and Society 3, no. 2: 156-177.

Keefer, Philip, and David Stasavage. 2003. "The Limits of Delegation: Veto Players, Central Bank Independence, and the Credibility of Monetary Policy.” American Political Science Review 97, no. 03 (2003): 407-423.

La Porta, Rafael, Florencio Lopez-de-Silanes, Andrei Shleifer, and Robert Vishny. 1999. “The Quality of Government.” Journal of Law, Economics, and Organization 15, no. 1: 222-279.

Lipford, Jody, and Bruce Yandle. 1997. "Exploring the Production of Social Order.” Constitutional Political Economy 8, no. 1: 37-55.

Lipford, Jody, Robert E. McCormick, and Robert D. Tollison. 1993. "Preaching Matters.” Journal of Economic Behavior \& Organization 21, no. 3: 235-250.

Marshall, Monty, Ted Gurr, and Keith Jaggers. (2013). Polity IV Project: Political Regime Characteristics and Transitions, 1800-2012. Center for Systematic Peace. 
Table 1: Description of Sources and Summary of Statistics for Variables

\begin{tabular}{|c|c|c|c|c|}
\hline Variable & Description & Source & Mean & Std. Dev. \\
\hline GRRI & Government Regulation of Religion index & $\begin{array}{l}\text { Annual Report on International } \\
\text { Religious Freedom }\end{array}$ & 2.905 & 2.988 \\
\hline GFRI & Government Favoritism of Religion index & $\begin{array}{l}\text { Annual Report on International } \\
\text { Religious Freedom }\end{array}$ & 4.721 & 2.681 \\
\hline $\begin{array}{l}\text { Religious } \\
\text { Fractionalization }\end{array}$ & Religious Fractionalization & Alesina et al. (2003) & 0.441 & 0.233 \\
\hline GDP $(\ln )$ & Natural Log of real GDP per capita, 2005 US\$ & World Development Indicators & 8.003 & 1.622 \\
\hline Literacy & Adult literacy rate, percentage & World Development Indicators & 78.519 & 21.001 \\
\hline Education & Secondary school enrollment rate, percentage & World Development Indicators & 71.195 & 31.241 \\
\hline Openness & Trade as a percentage of GDP & World Development Indicators & 88.853 & 49.763 \\
\hline $\begin{array}{l}\text { French Legal } \\
\text { Origins }\end{array}$ & French legal origins & La Porta et al. (1999) & 0.448 & 0.499 \\
\hline $\begin{array}{l}\text { German Legal } \\
\text { Origins }\end{array}$ & German legal origins & La Porta et al. (1999) & 0.029 & 0.168 \\
\hline $\begin{array}{l}\text { Scandinavian } \\
\text { Legal Orgins }\end{array}$ & Scandinavian legal origins & La Porta et al. (1999) & 0.029 & 0.168 \\
\hline Checks \& Balances & Idex for number of checks and balances & Keefer and Stasavage (2003) & 2.843 & 1.282 \\
\hline Democracy & Polity IV democracy rating & Polity IV & 5.373 & 3.750 \\
\hline
\end{tabular}

Note: Data from the World Development Indicators as well as Checks and Democ have been averaged from 1998-2008. 
Table 2:

\begin{tabular}{|c|c|c|c|c|c|c|}
\hline & $\begin{array}{c}(1) \\
\text { GRRI }\end{array}$ & $\begin{array}{c}(2) \\
\text { GFRI }\end{array}$ & $\begin{array}{c}\text { (3) } \\
\text { GRRI }\end{array}$ & $\begin{array}{c}(4) \\
\text { GFRI }\end{array}$ & $\begin{array}{c}\text { (5) } \\
\text { GRRI }\end{array}$ & $\begin{array}{c}(6) \\
\text { GFRI }\end{array}$ \\
\hline GDP (ln) & $\begin{array}{l}-0.208 \\
(0.262)\end{array}$ & $\begin{array}{c}0.467^{* *} \\
(0.208)\end{array}$ & $\begin{array}{c}-0.643 * * * \\
(0.238)\end{array}$ & $\begin{array}{l}0.374^{*} \\
(0.203)\end{array}$ & $\begin{array}{l}-0.356 \\
(0.262)\end{array}$ & $\begin{array}{l}0.424^{*} \\
(0.228)\end{array}$ \\
\hline Openness & $\begin{array}{c}0.001 \\
(0.006)\end{array}$ & $\begin{array}{l}-0.002 \\
(0.005)\end{array}$ & $\begin{array}{c}-0.005 \\
(0.005)\end{array}$ & $\begin{array}{l}-0.003 \\
(0.004)\end{array}$ & $\begin{array}{l}-0.009 * \\
(0.005)\end{array}$ & $\begin{array}{l}-0.004 \\
(0.005)\end{array}$ \\
\hline Literacy & $\begin{array}{c}0.018 \\
(0.017)\end{array}$ & $\begin{array}{c}0.002 \\
(0.013)\end{array}$ & & & & \\
\hline Education & & & $\begin{array}{c}0.019 \\
(0.012)\end{array}$ & $\begin{array}{c}-0.001 \\
(0.010)\end{array}$ & $\begin{array}{c}0.008 \\
(0.013)\end{array}$ & $\begin{array}{l}-0.003 \\
(0.011)\end{array}$ \\
\hline Religious Fractionalization & $\begin{array}{c}-2.922 * * \\
(1.149)\end{array}$ & $\begin{array}{c}-4.283^{* * *} \\
(0.909)\end{array}$ & $\begin{array}{c}-3.270 * * * \\
(0.930)\end{array}$ & $\begin{array}{c}-4.966^{* * *} \\
(0.792)\end{array}$ & $\begin{array}{c}-4.367 * * * \\
(1.038)\end{array}$ & $\begin{array}{c}-5.184 * * * \\
(0.906)\end{array}$ \\
\hline French Legal Origins & & & & & $\begin{array}{c}-1.305^{* *} \\
(0.530)\end{array}$ & $\begin{array}{l}-0.373 \\
(0.463)\end{array}$ \\
\hline German Legal Origins & & & & & $\begin{array}{l}-1.410 \\
(1.378)\end{array}$ & $\begin{array}{l}-0.171 \\
(1.203)\end{array}$ \\
\hline Scandinavian Legal Orgins & & & & & $\begin{array}{c}-3.278 * * \\
(1.398)\end{array}$ & $\begin{array}{l}-0.855 \\
(1.221)\end{array}$ \\
\hline Constant & $\begin{array}{c}4.674 * * * \\
(1.594)\end{array}$ & $\begin{array}{c}3.136^{* *} \\
(1.262)\end{array}$ & $\begin{array}{c}8.518 * * * \\
(1.366)\end{array}$ & $\begin{array}{c}4.159 * * * \\
(1.163)\end{array}$ & $\begin{array}{c}8.602 * * * \\
(1.453)\end{array}$ & $\begin{array}{c}4.340 * * * \\
(1.268)\end{array}$ \\
\hline $\mathrm{R}^{2}$ & 0.052 & 0.218 & 0.126 & 0.239 & 0.172 & 0.229 \\
\hline Adj $R^{2}$ & 0.0235 & 0.194 & 0.104 & 0.221 & 0.135 & 0.195 \\
\hline Countries & 137 & 137 & 167 & 167 & 164 & 164 \\
\hline
\end{tabular}


Table 3:

\begin{tabular}{|c|c|c|c|c|c|c|c|c|}
\hline & $\begin{array}{c}(1) \\
\text { GRRI }\end{array}$ & $\begin{array}{c}(2) \\
\text { GFRI } \\
\end{array}$ & $\begin{array}{c}(3) \\
\text { GRRI } \\
\end{array}$ & $\begin{array}{c}(4) \\
\text { GFRI }\end{array}$ & $\begin{array}{c}(5) \\
\text { GRRI }\end{array}$ & $\begin{array}{c}(6) \\
\text { GFRI }\end{array}$ & $\begin{array}{c}(7) \\
\text { GRRI }\end{array}$ & $\begin{array}{c}\text { (8) } \\
\text { GFRI }\end{array}$ \\
\hline GDP (ln) & $\begin{array}{c}-0.506^{* *} \\
(0.214)\end{array}$ & $\begin{array}{c}0.419 * * \\
(0.202)\end{array}$ & $\begin{array}{l}-0.259 \\
(0.231)\end{array}$ & $\begin{array}{c}0.458 * * \\
(0.226)\end{array}$ & $\begin{array}{c}-0.357^{*} \\
(0.188)\end{array}$ & $\begin{array}{c}0.429 * * \\
(0.208)\end{array}$ & $\begin{array}{l}-0.150 \\
(0.202)\end{array}$ & $\begin{array}{c}0.502 * * \\
(0.232)\end{array}$ \\
\hline Openness & $\begin{array}{l}-0.005 \\
(0.005)\end{array}$ & $\begin{array}{c}0.000 \\
(0.005)\end{array}$ & $\begin{array}{c}-0.009 * \\
(0.005)\end{array}$ & $\begin{array}{l}-0.001 \\
(0.005)\end{array}$ & $\begin{array}{c}-0.007 * \\
(0.004)\end{array}$ & $\begin{array}{l}-0.001 \\
(0.005)\end{array}$ & $\begin{array}{c}-0.011^{* *} \\
(0.004)\end{array}$ & $\begin{array}{l}-0.002 \\
(0.005)\end{array}$ \\
\hline Education & $\begin{array}{c}0.032 * * * \\
(0.011)\end{array}$ & $\begin{array}{c}0.002 \\
(0.010)\end{array}$ & $\begin{array}{l}0.020 * \\
(0.011)\end{array}$ & $\begin{array}{c}0.000 \\
(0.011)\end{array}$ & $\begin{array}{c}0.047^{* * *} \\
(0.010)\end{array}$ & $\begin{array}{c}0.010 \\
(0.011)\end{array}$ & $\begin{array}{c}0.037 * * * \\
(0.010)\end{array}$ & $\begin{array}{c}0.007 \\
(0.012)\end{array}$ \\
\hline Religious Fractionalization & $\begin{array}{c}-2.736 * * * \\
(0.830)\end{array}$ & $\begin{array}{c}-4.739 * * * \\
(0.785)\end{array}$ & $\begin{array}{c}-3.853 * * * \\
(0.909)\end{array}$ & $\begin{array}{c}-4.895 * * * \\
(0.888)\end{array}$ & $\begin{array}{c}-2.537 * * * \\
(0.726)\end{array}$ & $\begin{array}{c}-4.280 * * * \\
(0.802)\end{array}$ & $\begin{array}{c}-3.516 * * * \\
(0.773)\end{array}$ & $\begin{array}{c}-4.562 * * * \\
(0.885)\end{array}$ \\
\hline French Legal Origins & & & $\begin{array}{c}-1.465 * * * \\
(0.465)\end{array}$ & $\begin{array}{l}-0.330 \\
(0.455)\end{array}$ & & & $\begin{array}{c}-1.201^{* * *} \\
(0.401)\end{array}$ & $\begin{array}{c}-0.374 \\
(0.459)\end{array}$ \\
\hline German Legal Origins & & & $\begin{array}{l}-1.204 \\
(1.192)\end{array}$ & $\begin{array}{l}-0.242 \\
(1.166)\end{array}$ & & & $\begin{array}{c}-0.531 \\
(1.021)\end{array}$ & $\begin{array}{l}-0.341 \\
(1.169)\end{array}$ \\
\hline Scandinavian Legal Orgins & & & $\begin{array}{l}-2.312^{*} \\
(1.217)\end{array}$ & $\begin{array}{l}-0.729 \\
(1.190)\end{array}$ & & & $\begin{array}{c}-2.617^{* *} \\
(1.119)\end{array}$ & $\begin{array}{l}-1.403 \\
(1.281)\end{array}$ \\
\hline Checks \& Balances & $\begin{array}{c}-1.199 * * * \\
(0.163)\end{array}$ & $\begin{array}{c}-0.287^{*} \\
(0.154)\end{array}$ & $\begin{array}{c}-1.198^{* * *} \\
(0.161)\end{array}$ & $\begin{array}{c}-0.286^{*} \\
(0.158)\end{array}$ & & & & \\
\hline Democracy & & & & & $\begin{array}{c}-0.588^{* * *} \\
(0.053)\end{array}$ & $\begin{array}{c}-0.143^{* *} \\
(0.059)\end{array}$ & $\begin{array}{c}-0.580 * * * \\
(0.052)\end{array}$ & $\begin{array}{c}-0.139 * * \\
(0.060)\end{array}$ \\
\hline Constant & $\begin{array}{c}9.871 * * * \\
(1.241)\end{array}$ & $\begin{array}{c}4.207^{* * *} \\
(1.174)\end{array}$ & $\begin{array}{c}10.369 * * * \\
(1.312)\end{array}$ & $\begin{array}{c}4.392 * * * \\
(1.283)\end{array}$ & $\begin{array}{c}7.573 * * * \\
(1.074)\end{array}$ & $\begin{array}{c}3.493^{* * *} \\
(1.188)\end{array}$ & $\begin{array}{c}7.934^{* * *} \\
(1.119)\end{array}$ & $\begin{array}{c}3.567 * * * \\
(1.281)\end{array}$ \\
\hline $\mathrm{R}^{2}$ & 0.351 & 0.272 & 0.398 & 0.262 & 0.525 & 0.273 & 0.564 & 0.273 \\
\hline Adj $R^{2}$ & 0.330 & 0.248 & 0.365 & 0.221 & 0.508 & 0.247 & 0.539 & 0.230 \\
\hline Countries & 157 & 157 & 155 & 155 & 147 & 147 & 146 & 146 \\
\hline
\end{tabular}

Notes: ${ }^{*}, * *, * *$ denote statistical significant at the 10,5 , and $1 \%$ levels, respectively. Standard errors are reported in parentheses. 